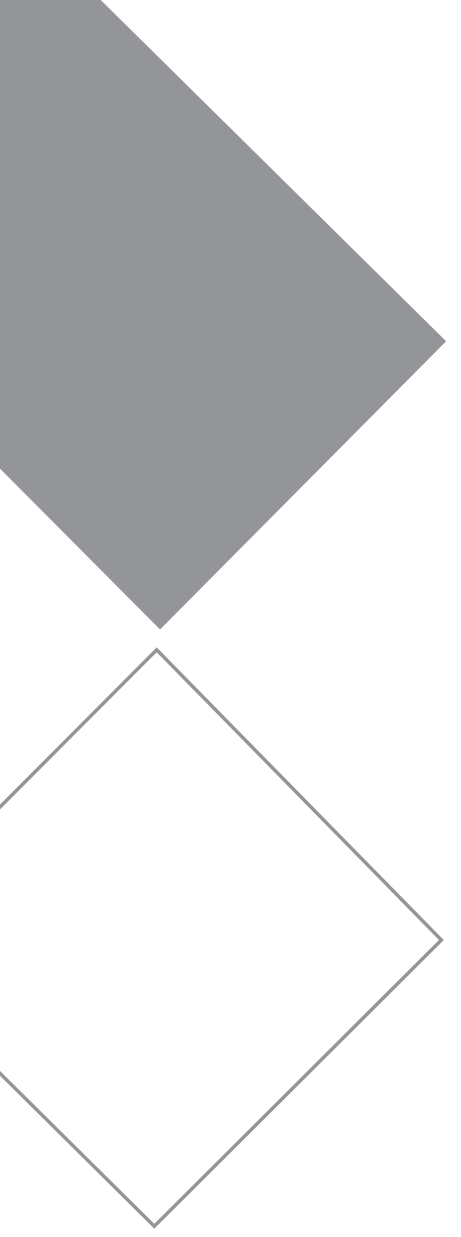

\title{
Jovens Mulheres \\ Africanas em Portugal: narrativas e itinerários
}

\author{
Neusa Maria Mendes de Gusmão \\ Doutora em Antropologia Social e \\ Antropologia da Educação da UNICAMP \\ neusagusmao@uol.com.br
}

\begin{abstract}
Resumo O presente ensaio relata os itinerários de duas jovens mulheres africanas, imigrantes em Portugal, com base em suas próprias narrativas. Na história de suas vidas, outras histórias se revelam para dizer o que é ser jovem, mulher, negra e imigrante num contexto europeu da atualidade. Suas narrativas encontram-se entremeadas pelas memórias da infância na África, ou mesmo em Portugal, e falam, também, da juventude vivida no bairro africano, Aldeia d’África, em terras portuguesas. Com isso, Portugal e África tecem a trama de seus cotidianos e permitem, por diferentes indícios, compreender a heterogeneidade das biografias, da memória e da cultura, tal como se apresenta na experiência pessoal de cada uma. Uma experiência que revela a história de muitas outras mulheres africanas em Portugal.
\end{abstract}

Palavras-chave: África; imigrante; narrativa; cultura; itinerário

\section{Introdução}

Trilhar um CAminho é estabelecer a possibilidade do encontro 1 com o outro, sujeito de experiências singulares e tecer com eles a trama da vida vivida, sua realidade e representação. Com essa intenção, o presente ensaio relata os itinerários de duas jovens mulheres luso-africanas $^{1}$, imigrantes em Portugal, com base em suas próprias narrativas.

$\mathrm{Na}$ história de suas vidas, outras histórias se revelam para dizer o que é ser jovem, mulher, negra e imigrante num contexto europeu da atualidade. Suas narrativas encontram-se entremeadas pelas memórias da infância na África, ou mesmo em Portugal e falam, também, da juventude vivida no bairro africano ${ }^{2}$ em terras portuguesas. Com isso, Portugal e África tecem a trama de seus cotidianos e permitem, por diferentes indícios, compreender a heterogeneidade das biografias e da própria experiência pessoal.

Como afirma Moore (2000, p.16) "cada indivíduo tem uma história pessoal, e é na interseção dessa história com situações, discursos

10 termo luso-africano designa grupos de negros africanos que emigraram dos Países Africanos de Língua Oficial Portuguesa (PALOP), ou seja, de Angola, Moçambique, Guiné Bissau, Cabo Verde e São Tomé e Príncipe para Portugal e que possuem nacionalidade portuguesa ou não.

2 Bairros africanos, denominados como Aldeias d'África, são bairros de invasão, assemelhados as favelas brasileiras e, também, são conhecidos como Bairros de Lata. Resultam de uma maioria africana que os habita em condições precárias. Bairros assemelhados existem dentro e fora de Lisboa. 
e identidades coletivas que reside a relação problemática entre estrutura e práxis, e entre o social e o indivíduo". Para a autora, formas de subjetividade ou tipos de subjetividade que perpassam as histórias individuais são sempre "marcadas por estruturas de diferença fundadas no gênero, na raça, na etnicidade e assim por diante" (Moore, 2000, p.16) e, ainda segundo ela, cada um desses aspectos consiste em uma construção social.

Por essa razão, a experiência social, como diz Dubet (1994), ocorre como parte da experimentação da vida em termos cognitivos e emocionais, resultando em diferentes formas de construção do real. Tais formas são produto da heterogeneidade do social e são, elas mesmas, heterogêneas. Com isso, duas jovens luso-africanas ocupam aqui o palco, mas entre semelhanças e diferenças presentes em seus trajetos pessoais, demonstram a existência de uma multiplicidade de modos de se ser africana e luso-africana, de se ser mulher e jovem em Portugal. Vivem aí, as contradições postas pelo contexto da imigração, da raça, apreendida por meio da condição étnica e da cor e, ainda, por uma dimensão social de classe. Quem, portanto, são essas jovens mulheres?

Vivi - em verdade, Evelize - e Marizete são jovens negras, imigrantes, uma de origem sãotomense e outra angolana. Cresceram e viveram parte de suas vidas no bairro degradado de Quinta Grande, um bairro de lata da Freguesia da Charneca e, até final dos anos de 1990, na periferia da cidade de Lisboa ${ }^{3}$. Hoje, a Quinta Grande não mais existe, posto que, em maio de 2001, seus moradores foram realojados num bairro de Habitação Social ${ }^{4}$ ou bairro social como são chamados. O bairro social foi construído em área próxima ao antigo bairro, agora demolido e, é parte de um grande complexo habitacional de natureza mista (realojamento e condomínios particulares) chamado Alta de Lisboa. Expressão do avanço e modernização urbana sobre áreas de ocupação mais rarefeita, o bairro social é, também, expressão das chamadas políticas sociais originadas em razão da migração extracomunitária, vista como problemática para os planos da União Européia.

Entre os dois momentos da existência da Quinta Grande e seu fim, as histórias de Vivi e Marizete foram alteradas e, de suas trajetórias configuram-se os nexos do que aqui é parcialmente narrado. Nessa exposição, os relatos de Vivi e Marizete implicam um percurso pouco comum para os debates da juventude e da imigração, cuja tradição tem sido, o estudo desses sujeitos como à margem da vida social e como sujeitos de exclusão que vivenciam contextos de risco, não captando outros trajetos possíveis que não a própria marginalidade.
As vivências de Vivi e Marizete permitem pensar, tal como é proposto por Pais (1993), que o jovem deve ser compreendido como aquele que vivencia uma fase da vida que, para além da idade, experimenta diversos modos de ser, fruto das demandas sociais por mobilidade geracional, reprodução cultural e social. O jovem encontra-se, assim, imerso no cruzamento entre identidade e mudança. Diz ainda, o autor, que "a juventude constitui-se, de certa maneira, como um laboratório ou cenário de mudança das estruturas sociais"(Pais, 1993, p.35). Nesse sentido, como alguém que vive a transição para um momento novo, desejado e temido, por aquilo que vê e compreende na vivência com seus pares, o jovem é alguém que experimenta o mundo social e tece em relação a ele sonhos, desejos, expectativas e valores. São esses aspectos que ressaltam das narrativas dessas duas jovens luso-africanas e, neles, as desigualdades do meio social e o projeto de uma maior participação e reconhecimento exige pensar e repensar os mecanismos de formação do sujeito negro e os caminhos pelos quais tem construído uma perspectiva de si, no interior de contextos como os aqui considerados. Sabe-se que os caminhos de integração e participação na sociedade não são lineares ou únicos para nenhum dos envolvidos, sejam estes os sujeitos sociais ou a sociedade em que estão inseridos.

O desafio é entender no interior dessas trajetórias, as possibilidades de identificação e de identidade e, ainda, a visão de mundo entre negros "estrangeiros", já que o confronto com a sociedade inclusiva, seja no âmbito da família, da escola, do trabalho, do lazer e outro, supõe que sejam criados mecanismos de adaptação social. Tais mecanismos esbarram em resistências e conflitos tanto para os primeiros luso-africanos como para as gerações mais novas - os luso-africanos nascidos em Portugal, cuja identidade está em formação.

\section{A história de Vivi}

Vivi sempre viveu em casa de parentes próximos no interior do bairro degradado, a Quinta Grande e, após uma série de desentendimentos envolvendo relações conflitivas com seus parentes, teve reconhecido seu direito de moradia no bairro social. Vivi, em 2001, aos 22 anos de idade, ganhou autonomia e recebeu um apartamento no bairro social para morar, apesar de ser solteira e não ter família, uma das condições do governo para a atribuição desse direito. Na história de Vivi, a continuidade da história comum dos moradores do bairro, que se transferem do bairro degradado para o bairro 
social. Trata-se, porém, de uma continuidade em termos, já que tendo vivido sempre no bairro de invasão, nele construiu uma vivência em tudo semelhante ao de outros imigrantes e própria dessas Aldeias d'África. Seguiu com amigos, conhecidos, vizinhos e parentes para a área do realojamento, mas não nas mesmas condições que eles, com suas famílias extensas e quase nenhum hábito relativo a uma vida em prédios. Porém, não só quanto ao bairro social ela se diferencia.

A própria conquista da moradia no realojamento, resulta de sua trajetória pessoal em que, se o trajeto percorrido foi o mesmo que o de qualquer imigrante, não o foi enquanto luta para alcançar uma condição melhor e mais significativa até, do que a dos seus pares. Vivi, através da dedicação aos estudos e ao trabalho, distanciou-se gradativamente das trajetórias juvenis do bairro de lata, porém, manteve sempre, intensas relações com seus moradores e, especialmente, com os jovens, seus amigos. Hoje, é presença conhecida e reconhecida entre os moradores do bairro social, ex-moradores da Quinta Grande, por meio de sua atuação em projetos sociais do Instituto de Solidariedade e Cooperação Universitária ${ }^{5}$. Seu papel é o de ser mediadora comunitária entre as famílias e as escolas da Charneca, nomeadamente, a EB1 n.66 e a EB2 Pintor Almada Negreiros, condição alcançada por meio da qualificação em curso ministrado pelo ISU e apoiado pela União Européia.

Uma voluntária do ISU afirma:

Ela (Vivi) cresceu naquele bairro, ela conhece toda a gente. Conhece as famílias todas, os miúdos (crianças) todas. Além de ter feito todo o curso dela conosco, desde ela pertencer ao ATL, ter sempre pertencido ao Espaço Jovem. Ela fez o curso de Agente de Desenvolvimento Local.

Vivi, como outros jovens, foi acolhida pelo ISU,

Eu comecei a trabalhar com o ISU, ou melhor o ISU começou a trabalhar com nós, os jovens, as crianças do bairro, pois na altura eu era mais pequenina, depois trabalharam, nós fizemos varias atividades. Primeiro iam integrar-se na família para depois chegar a nós. Porque eles chegaram lá e agarraram logo as crianças e foram fazer atividades. Ele (Joãozinho do ISU) soube se integrar muito bem na família. E ganhou muita confiança da nossa parte, das crianças.

Vivi freqüentou a Escola de Ensino Básico de Primeiro Ciclo EB1 n.66, na Charneca, participou da
Atividades de Tempos Livres (ATL) e, também, espaço de atendimento escolar (Apoio Escolar) e, por fim, integrou as atividades do Espaço Jovem, sob coordenação do ISU. O Espaço Jovem congregava vários grupos de jovens da Quinta Grande - Black Angels; Black Selection; As Imparáveis, entre outros -, organizados em torno de diversas atividades, entre elas a dança (de músicas africanas tradicionais e/ou RAP), os clubes de férias, festas no bairro, grupo de teatro etc., chegando alguns dos grupos de danças a se apresentarem em outros países da Europa. Todos integrados em projetos sociais levados pelo ISU, com o apoio da União Européia e Ministério do Trabalho e Solidariedade, de Portugal. Vivi, nesse processo, se faz personagem típica do Bairro da Quinta Grande e de seus jovens. No final da década de 1990, Martins (1997, p.130), a descrevia como:

Exímia executante de danças africanas, usa longas tranças postiças (à semelhança de outras miúdas de seu grupo de dança) que a fazem notar espetacularmente. (...) [veste-se] com gangas ou vestidos curtos que salientam as formas de seu corpo. Calça, normalmente, umas botas de cano alto com um salto grande, que lhe proporciona uma forma provocante de andar.

Vivi, em 1998, tinha 18 anos e envolvia-se nas atividades do ISU, com grande capacidade de liderança e discernimento, compreendendo a realidade do Bairro de Lata e, lutando por um lugar melhor, não só para ela, mas para todos. Era assim, muitas vezes, intermediária entre os agentes externos do ISU e os moradores. Mediava conflitos e encaminhava processos de atuação no interior do bairro, não foi, portanto, por acaso, que o ISU lhe proporcionou uma formação especializada. Vivi ao mesmo tempo em que procurava se qualificar para não sofrer os revezes do mercado de trabalho, trabalhava intensamente em empregos precários, em horários estressantes e de pouco descanso. Nesse contexto, capacita-se mediante os cursos de qualificação que são oferecidos, mas não chega a terminar a escolarização obrigatória, tendo estudado até o $10^{\circ}$ ano $^{6}$. Apesar disso, pode-se dizer que sua trajetória é pouco comum para a maioria dos jovens de seu bairro, fadados ao insucesso escolar, ao abandono precoce da escola e, em geral, conduzidos a uma vida de transgressões e marginalidade.

Nesse pano de fundo, Vivi fala de sua vida em Portugal e de seu nascimento em São Tomé. Diz ela:

5 Instituto de Solidariedade e Cooperação Universitária (ISU), uma ONG que presta assistência aos moradores da Quinta Grande, em especial, as crianças e os jovens, através de diferentes projetos, entre eles o Atividades de Tempos Livres (ATL) e o Espaço Jovem, grupos associativos de jovens voltados para diferentes atividades.

6 A escolaridade obrigatória e pública em Portugal compreende nove anos, divididos em três ciclos: o primeiro ciclo que compreende da $1^{\text {a a }} 4^{\text {a }}$ série; o segundo ciclo que vai da $5^{\mathrm{a}}$ a $7^{\mathrm{a}}$ série e, o terceiro ciclo que corresponde a $8^{\mathrm{a}}$ e $9^{\mathrm{a}}$ série. Finalmente, têm-se a Secundária que vai até o $12^{\circ}$ ano de escolaridade e após o qual se está habilitado para ingressar na universidade. 
Eu vou começar a contar minha história desde que cheguei a Portugal. Eu sou sãotomense, sai de São Tomé com 4 anos de idade. Era para estudar em Angola mas minha mãe não quis porque não tinha condições de estudar lá. Então fiquei em Angola uns anos e depois vim para cá, para Portugal.

(...)

Quando cheguei, fui morar no bairro da Quinta Grande, fica na Charneca, onde minha tia tinha uma casa. A minha mãe, era caixeira viajante, não tinha muito tempo para ficar comigo, então fiquei sob responsabilidade da minha tia, irmã da minha mãe. Fiquei na Quinta Grande, fui matriculada na escola 66 da Charneca, onde fiz a primaria, depois da primaria fui para a Pintor, antiga escola da Pintor Almada Negreiros. Depois sai da Pintor fui para (?) onde estudei. Pronto, já não adiantei mais os estudos. Acabei por tirar um curso de Agente de Desenvolvimento Local, que foi feito pelo ISU, onde eu tive que fazer estágio na escola 66, o que eu achei muito engraçado porque foi uma escola que eu estudei. Eu voltei lá para trabalhar. Para mim foi uma experiência muito agradável.

Vivi, comenta que teve muitos problemas familiares, tanto com a tia, como com o padrasto, companheiro de sua mãe, se fazendo, assim, uma adolescente problemática. Reconhece que poderia, em razão dos fatos, da idade e das oportunidades de um Bairro de Lata, ter assumido um caminho sem volta, referindose ao mundo das drogas e da marginalidade, tal como aconteceu a muitos dos que conheceu na Quinta Grande, mas diz: "tive muitos problemas na vida e Graças a Deus consegui superá-los, a todos, até agora”.

Agora, aos 22 anos, relembra as dificuldades com o padrasto e o quanto tudo aquilo mexeu com sua cabeça, já que tinha apenas 14, 15 anos de idade.

Aquilo foi uma grande confusão, já não sabia o que era bem, o que era mal. Trabalhava e estudava ao mesmo tempo para me sustentar. Antes disso. Meu padrasto falava para minha mãe que eu fazia certas coisas que eu não fazia e eu achava que era mentira por que era mentira mesmo, tinha certeza. Minha mãe chegava em casa e me batia. Estava constantemente a bater-me. Eu muitas vezes perguntava por que ela estava a me bater e ela dizia que era porque meu padrasto disse isso e isso e isso, e que é verdade. Eu dizia não, não é verdade. Não pode afirmar uma coisa que não é verdade, que tu não viste. Me arranhava, tinha a cara toda marcada. Ia para escola toda arranhada. Então, eu tomei uma decisão de que eu não podia mais viver com ela. $\mathrm{Na}$ altura, eu saí de casa e fui viver na casa de uma amiga. Minha mãe foi ter comigo na casa dessa amiga, dizendo que era para eu voltar. Eu disse que não voltava.. Ela disse és muito nova para estar ai, nunca trabalhastes, como é que vais te sustentar? Eu disse não, há sempre uma primeira vez para tudo. Se sai de casa era porque não estava a me sentir bem, e não vou voltar para lá outra vez. Não vou parar de estudar e vou trabalhar ao mesmo tempo, porque aqui há muitos trabalhos que se pode trabalhar e estudar ao mesmo tempo. Se muitos fazem, eu também posso fazer.

Diante da determinação da filha, a mãe lança mão de uma prática comum na África, pedindo a uma tia mais velha, tia-avó de Vivi, que fosse buscá-la para viver com ela e não com estranhos. Vivi morou com essa tia-avó até ir para seu próprio apartamento no bairro social e nunca aceitou voltar a morar com a mãe. Foi assim, portanto, que, como diz, teve que trabalhar e estudar ao mesmo tempo. Trabalhou muito tempo em uma pizzaria, sempre alternando o horário de trabalho com o horário escolar. Lá,

Eu atendia o público e era (?) em cozinha. Era rotativa, fazia de tudo um pouco. Pizzas é o que nunca fiz. Quer dizer, fiz algumas coisinhas, todas tortas, não para vender, só para nós comermos. Sai de lá, sai do Pizza na Brasa, estava um bocado cansativo, aquilo.

Depois, quando saiu de lá, foi trabalhar num café, e como diz, "se eu for contar todos meus trabalhos. já fiz tantos...". O café era no interior da própria Quinta Grande e, seu dono, um amigo que condoído da situação de Vivi e, para não vê-la dependente de outras pessoas, a convida para trabalhar lá. Vivi, confirma:

Vivi, tu vens prá aqui. Trabalha conforme teu horário escolar e nem que for o mínimo eu dou-te. Para não estar aqui a depender de outras pessoas, para depois mais tarde não virem falar. Eu também, Graças a Deus, não tenho preguiça, nem sou preguiçosa em termos de trabalho, então aceitei. Trabalhei no Seu Silvino, depois sai do Seu Silvino fui trabalhar nas limpezas, onde trabalhava até as 6 da manhã.

O novo trabalho era já, para firma estabelecida, mas não havia carteira de trabalho, nem os direitos decorrentes do trabalho eram garantidos. Como imigrante não era ainda legalizada, como é hoje, e, também não sabia como essas coisas funcionavam, ficando a mercê do empregador, como tem sido o caso de grande parte dos imigrantes em Portugal.

Vivendo a tanto tempo em Portugal, Vivi sempre percebeu e criticou a violência e a condição desprivilegiada que o negro vive em Portugal. Expressa sua visão de mundo, afirmando:"eu gosto, gosto do ambiente (de Portugal), gosto de tudo. Só não gosto é da guerra. De vez em quando há umas guerras que andam por ai..."

A questão da "guerra" diz respeito ao racismo português, mas não só, já que ocorre também entre africanos de origens diversas. Vivi e uma amiga chamada Vânia, falam dos conflitos que enfrentaram nas 
escolas pelas quais passaram e do racismo que, muitas vezes, ainda sofreram, tanto por parte dos alunos, como dos professores. Muitas vezes foram maltratadas pelos próprios colegas e sofreram muitas injustiças por parte dos professores. Sua fala revela, em grande parte, uma das razões de jovens imigrantes não permanecerem na escola.

Porque eu tenho que fazer amizade com algumas pessoas... para [me defender?] delas. Ah, começo a fazer amizade e eles começam a luta, porrada. E eu digo: "eu não vou fazer porque eu tô...". E eles dizem:"mas nós não queremos”. Então eu vou-me embora. Vou fazer amizade com outras pessoas.

(...)

Por causa... não tem... comigo. Eu digo: "pára de se meter”, ele diz:.. Eu digo: Pá!!! (grita) para dar uma chapada (?). E aí... eu tenho medo... da professora que é branca...

Desde sempre, Vivi percebe e compreende a existência do racismo em Portugal, mas percebe que também há pessoas que não são racistas e, que uns e outros, tanto podem ser brancos, como podem ser negros. Com isso, estabelece possibilidades de convivência com negros e com brancos portugueses, os "pulas", chegando mesmo a ter um namorado branco por muito tempo. Namorar com brancos é cada vez mais comum, não só nos bairros precários, mas, também, no mundo português como um todo. Em muito contribui para isso, a realidade dos bairros precários que reúnem, num mesmo espaço, imigrantes africanos dos PALOP e, também, migrantes portugueses do norte de Portugal, entre outros grupos migrantes da Ásia e da India. Nesse sentido, a Quinta Grande foi compreendida por Martins (1997) como um "espaço de amizades interculturais" e, enquanto existiu, até maio de 2001, foi percebida por seus moradores como um lugar bué de fixe (muito legal, bom).

O bairro da Quinta Grande não apresentava conflitos raciais alarmantes, talvez graças à convivência necessária entre brancos e negros, que ocupavam, quase na mesma proporção, o mesmo espaço. A boa convivência pode ser percebida, também, na seguinte fala de Vivi:

... Por isso que eu digo, os pulas [portugueses brancos] vão mudando, qualquer dia são mais pretos do que brancos. Pode ser. Por vezes, eu também posso parecer branca, mas sou pretinha. Outras vezes os brancos são mais pretos do que eu, como tu, percebestes?

Por essa razão, hoje, após a demolição do bairro e o realojamento, a maioria das falas dos ex-moradores, afirmam o bairro como "uma maravilha". Vivi deixa claros os sentimentos para com o lugar, dizendo:
Dávamo-nos todos bem, não havia aquela contradição que normalmente de ser preto, de ser branco, de ser chinês, de ser indiano e de ser não sei o que. Nada. Aquilo era uma maravilha. Eu morei na Quinta Grande muitos anos. Há pessoas que me viram lá pequenina e me vêem agora uma mulher. (...). Eu fazia muitas coisas na Quinta Grande. Era, era diferente. Então, nós aqui na Quinta Grande éramos como uma família, uma só grande família. Tudo o que fazíamos era em conjunto. Branco, preto, tudo. Não havia diferenças.

Por essas lembranças entendem-se as razões pelas quais o realojamento, se foi bom, por ter dado casas mais dignas para se morar, também trouxe a perda da intensa convivência existente no bairro precário. Vivi fala que o realojamento "foi bom. Mas no outro [lado] não foi porque ficamos separados [os moradores]. Foi triste". Os jovens agora, não têm um lugar seu, ficam espalhados pelo bairro social "espalhados pelos prédios... não ficam mais juntos...”.

\section{A história de Marizete}

Marizete, desde sempre, viveu no bairro da Quinta Grande, mas pouco teve a ver com ele, já que, em seu cotidiano, vivia dele distanciada em razão de seus estudos de período integral e de sua escola estar situada mais ao centro da cidade de Lisboa. Em 1998, ela mesmo dizia, meio envergonhada que,

Eu vivo naquele bairro mas sei muito pouco daquele bairro. Praticamente vivi mais fora do que dentro (...) convivo com pessoas das nove da manhã até as oito horas da noite (...) porque fico na escola ..., com pessoas portuguesas...

Morando na casa de uma tia, era impedida de grande convivência com os jovens de sua idade, em razão do péssimo exemplo que eles poderiam ser em sua vida, diante do projeto familiar de fazê-la cumprir, com sucesso, uma trajetória educacional e de mobilidade social. Marizete fala do relacionamento difícil com a mãe que ficou na África, mas que prédeterminou o que ela deveria cumprir em Portugal. "Minha mãe e minha avó (com quem também viveu), eram muito autoritárias. O que eu quero tá feito e acabou'. Em suas lembranças, Marizete lembra-se sempre da escola, desde o pré-primário e da mãe a dizer "ela tem que fazer isso (estudar) e ela me obrigava a fazer. Ia para a escola...minha mãe é do tipo que exige perfeição em tudo!’. Marizete ainda complementa que, para a mãe devia-se seguir tal qual o comboio ${ }^{7}$, 
sempre na mesma linha que, nesse caso, era estudar para chegar a algum lugar.

A história de Marizete, colhida por Martins (1997, p.129) é, então, narrada por ela a partir de seu nascimento e da intensa mobilidade geográfica de seus pais, a mãe sãotomense e o pai angolano.

Nasci em Angola, vivia em Luanda na zona de Escoqueiros até os três anos(...)na separação dos dois [refere-se aos pais], tinha eu três anos, minha mãe levoume a São Tomé e os meus três irmãos. Poucas vezes eu poderia estar com ele [pai], sendo ele um marinheiro. A minha mãe trabalhava no Banco Nacional de Luanda, a função dela era qualquer coisa como secretária. (...)

A casa onde eu vivia em Santa Catarina era uma vivenda grande. A casa estava rodeada de vários tipos de flores tropicais (...) tinhamos vários animais (galinhas, patos, coelhos, alguns porcos e três cães). Com uma distância de trezentos metros, de minha casa, havia uma linda praia rodeada de coqueiros e flores na areia.

(...)

Em finais de setembro de 87 fui viver para Angola, propriamente em Luanda, na Maianga/Serpa Pinto. A casa onde eu vivia era um prédio/vivenda de dois andares. A primeira noite que lá cheguei achei aquelas pessoas um pouco estranhas. Tratavam a minha mãe por tia, mana, Bia, como se fossem mesmo da família deles. Perguntei a minha mãe se essas pessoas eram família de meu pai, ela apenas comentou: 'Por respeito e amizade tratam assim os amigos'.

(...)

Em abril de 1988 regressei a São Tomé com minha mãe e quase todos os meus familiares acharam que eu tinha mudado. Principalmente, a nivel da linguagem e de alguns hábitos. Os sãotomenses são pessoas com muitos hábitos e acham que os seus hábitos são superior aos outros. Em relação aos angolanos, a maioria vive com seus hábitos, mas dão muita importância ao próximo.

(...)

Em abril de 89 vim viver para Portugal. Quando cá cheguei ao aeroporto não gostei nada de Portugal; sai do meu país com tanto calor e aqui 'é uma arca frigorífica'. Pior estava para chegar, apanhando o táxi cheguei a uma zona de nome Charneca, propriamente Quinta Grande. Odiei o lugar onde iria viver, ao princípio disse a minha mãe que iria regressar no mesmo dia para Luanda. No mesmo dia.. Nunca tinha passado pela idéia que um dia iria viver num bairro como este.

(...)

Em setembro de 89 tive que recomeçar os estudos. Fui estudar a terceira classe para a escola primária EB1 n.66 da Charneca.

(...)

Quando entrei a primeira vez na minha (sala 13) não estive alegre, aquelas pessoas eram estranhas e sentiame estranha. Tive dificuldade...
Marizete, em 1998, tinha dezenove anos, dez dos quais vividos em Portugal e na Quinta Grande, um bairro degradado. Nessa idade, sabe o que é ser imigrante, posto que tenha transitado primeiro pelo mundo africano, entre São Tomé - Angola - São Tomé e, depois, Portugal. Desenvolve aí seus estudos e uma imensa curiosidade em entender o que é ser africano em Portugal e que dificuldades isso implica. Motivada pela própria história e por ter que fazer um trabalho escolar, desenvolve uma pesquisa pessoal sobre o tema, tendo ajuda de um jovem pesquisador português que também trabalha com imigrantes africanos, escreve, então, uma reflexão com o título: Cultura, aculturação e mudança social (Francisco, 1998, mimeo.). Com isso, justifica seu interesse, para além da atividade escolar, em razão de ser ela, quem é, ou seja, uma pessoa formada por diferentes culturas que envolvem a África e, também, Portugal. Diz então, querer:

...tentar conhecer melhor a situação dos africanos aqui em Portugal. Embora eu sou africana, tenho uma visão...da minha vivência e não da dos outros em geral. Eu queria conhecer para fazer um trabalho [de ajuda, cooperação], não sei...e cada vez que eu encontrava material para o meu trabalho eu ficava completamente de boca aberta (,,,) discriminação, mas eu não tinha notado que era assim tão grave. (...) Desse meu trabalho, a visão que eu fui tirar é que não é fácil ser imigrante aqui em Portugal. Muitas pessoas vêm, muitas pessoas africanas vêm em busca de melhores condições de vida aqui em Portugal. Mas, nem bem chegam recebem logo um rótulo: o bairro degradado.

O bairro degradado, Quinta Grande ou outros, aos quais são encaminhados os imigrantes que chegam, constitui-se em elemento de diferença e discriminação, configurando-se como um lugar de exclusão social - "Nem bem chegam, eles (os imigrantes) recebem um rótulo: o bairro degradado". Para Marizete, resulta daí seu projeto pessoal de chegar à universidade. Pensa em estudar psicologia, apesar de ter paixão pelo teatro "...aí, tudo é vida, é emoção, é tudo..., mas indo para a faculdade eu poderia ter mais conhecimentos. E psicologia pra me conhecer ainda melhor e teatro pra mim realizar um sonho de uma escola superior".

Em 1998, Marizete estudava num curso técnico de Animador Sociocultural, que lhe daria a equivalência do $12^{\circ}$ ano da escolaridade (Secundária) e, após o qual se encontraria habilitada para ingressar numa faculdade. Embora já estivesse formada desde 1999, em 2002, ainda não tinha acontecido de chegar a uma faculdade e, encontrava-se sem perspectivas de poder fazê-lo, em razão do trabalho de muitas horas por dia. No entanto, sua trajetória até o final do curso técnico, foi coberta de sucesso, o que a diferencia de outros jovens imigrantes, já que esse não é o caminho da maioria dos jovens luso-africanos. 
O curso técnico feito por Marizete foi subsidiado por uma bolsa governamental e exigiu dedicação de tempo integral, com boas notas e nenhuma reprova. No entanto Marizete era e é pobre, tal como os demais imigrantes e, com isso, só podia estudar porque era subsidiada, mas fazia o impossível para ganhar algum dinheiro extra nos poucos intervalos de suas obrigações escolares. Assim, esporadicamente ou nas férias, cuidava de crianças pequenas, para o que, muito lhe valia o curso de baby sitter e, também, o de cuidados básicos em enfermagem. Entre os alunos de sua conceituadíssima escola, ela era uma entre os cinco estudantes de origem africana e, a única mulher negra que aí estudava. Fazia imensos sacrifícios para tal, trabalhando nos períodos de férias escolares para poder comprar seus cadernos e livros. Esses fatos seriam, também, partes das razões pelas quais Marizete não conviveu mais intensamente com as pessoas de seu bairro, vivendo mais tempo de seu dia, longe dele e entre os portugueses. $\mathrm{O}$ que não significa que não conhecesse os problemas do bairro africano e de sua gente, tanto que até hoje, através do ISU e de seus colaboradores, participa de grupos e de reuniões que desenvolvem atividades com os jovens e crianças da ex-Quinta Grande, ocupando suas noites e mesmo seus finais de semana com eles. A razão é a mesma de Vivi, a compreensão de que não é fácil ser imigrante, pobre e negra em Portugal.

Além da discriminação nos transportes coletivos, na escola e mesmo no próprio bairro, assume, então, como necessário, qualificar-se para o mundo do trabalho, por meio de vários cursos, já que, Marizete, para além do curso de baby sitter e enfermagem, fez também, informática e inglês, tendo por meta cumprir seu projeto pessoal - que era, também, o de sua mãe - de mobilidade pela via educativa e distanciando-se dos riscos permanentes da vida à margem oferecida pelas condições do Bairro de Lata e pela sociedade portuguesa.

O contexto de sua vivência repercute, até hoje em sua vida e no seu modo de ser. Conta aí, a multiplicidade de suas experiências como imigrante, mas também a importância que ela e sua família sempre deram aos estudos para superação dos limites concretos postos por uma situação de classe e, decorrentes da emigração. Como ela própria diz e acredita, ainda hoje, "o meio que a pessoa está também influencia bastante. (...) E eu posso dizer que há algumas coisas em mim que mudou, não tudo, mas algumas coisas..."

Ou ainda, porque

Sou aquilo e muito mais e mais outra coisa, porque eu convivo com pessoas (portuguesas), moro em casa africana eh... eu convivo com pessoas portuguesas, com uma maneira de estar...

(...)

Então eu continuo a ser uma africana-portuguesa. P: Africana-portuguesa?
R: Africana-portuguesa porque assim... quando eu estiver com meus irmãos e com minha avó... eles vão notar uma grande diferença em mim...

Marizete acredita que a convivência com os portugueses a fez mudar no tocante seu jeito de ser, se portar, pois, os jovens de "segunda geração", não são portugueses, mas, também não são totalmente africanos e, "ser imigrante é precisar adaptar-se à realidade". O que não é simples.

Muitas pessoas vêm, muitas pessoas africanas vêm em busca de melhores condições de vida aqui em Portugal, - ou seja, eles mal chegam cá, ganham um rótulo: o bairro degradado. E depois, - se você quer um empréstimo, coisa assim, não consegue. - tanto é que eu já senti na pele.

Hoje acho que a situação de trabalho está pior mil vezes que lá (Angola, Cabo-Verde, África em geral), a pouca história de Quinta-Grande começou com os imigrantes cabo-verdianos. Tanto é que há poucos momentos atrás eu vivia lá (no Bairro de Lata) e não via tantas pessoas como existe agora, porque de 90 para cá, houve um número grande de pessoas migrando pra cá. Chegaram cá por causa de Angola, estourou-se uma segunda guerra em Angola que foi terrível..."

Mesmo sabendo disso, Marizete, fala que se pudesse escolher "de maneira alguma trocaria a vida que eu tive [na África] para viver como vivo". Ao mesmo tempo, afirma que é difícil viver com seus parentes que estão em Portugal há décadas. A razão é que eles "não aderiram a certos hábitos, pensam como se estivessem em São Tomé. Nem sempre é fácil manter um diálogo com eles. Geralmente as respostas são: "não te esqueças que não és branca, nem tão pouco portuguesa"(Martins, 1997, p.129). Esse tipo de pressão também a levou a deixar o bairro e viver sozinha e depois, a alugar um apartamento em outro Concelho, próximo de Lisboa, para aí viver com seu primeiro namorado, um africano. No entanto, admite que haja coisas, as quais pensa como alguns portugueses pensam, há outras que não e que não se trata de ser branca no modo de pensar ou de ser aquela mulher negra que já tem curso médio ou um curso superior, mas de reconhecer a necessidade de condições básicas para algumas coisas na vida, ter filhos, por exemplo.

No caso da mulher africana, ter filhos é importante e todos lhe cobram quando terá os seus. Responde sempre que

só tenho 23 anos, moro numa casa alugada, o salário é pouco, quer dizer, não há contrato, nem nada disso e, claro, não posso pensar em ter filhos, não é? Não sem as condições mínimas para lhe dar escola, creche, vestuário. Tudo que precisa. A situação atual é tão caótica que não é que se diga às pessoas para não Ter 
filhos. Por isso, penso que mulheres africanas devem sim, querer ter uma profissão, mesmo estando casadas

Quanto à migração africana, sua história mostra que, na maior parte dos casos, as pessoas não vêm direto para Portugal quando migram. Muitos vão antes para Angola ou para São Tomé, ou ainda, para Cabo-Verde, circulam um pouco no próprio mundo africano, para depois virem para Portugal e, com isso, se transformam. Poucos são os que saem de seus países diretos para Portugal. Esta parece ser a razão da formação de famílias que contam com pessoas de diferentes origens - sãotomense e angolana, por exemplo, como é o caso de seus pais e dela própria, que nascida em São Tomé, vai para Angola, retorna a São Tomé e, depois vem para Portugal, onde afirma ser uma africana - portuguesa e angolana.

Sua ambigüidade e ambivalência como portadora de várias influências culturais adquiridas dos espaços em que viveu na África e em Portugal, muitas vezes, questionada por seus parentes ou amigos, a faz reconhecer que pesa a condição de ser mulher e africana. Pouco se pode contar com o homem africano, mesmo quando estes admitem que o trabalho da mulher seja difícil, a elas cabem cuidar da casa, dos filhos e do companheiro. Não ajudam e dizem não fazê-lo porque "o fato de estarem na Europa não lhes muda a identidade. E não muda mesmo!" Porém, diz Marizete, seus desentendimentos com o namorado, vêm do fato de que acredita que as mulheres não foram feitas para cuidar de casa. Aqui, diz ela, os homens africanos dizem que sou portuguesa ou como querem meus parentes, não devo esquecer que não sou branca.

Por tudo isso, ser africano do meu ponto de vista, diz Marizete, envolve dois tipos de africanos. Aquele africano que tem uma vida econômica estável e aquele africano que tem uma situação econômica baixa e que vai ter que sobreviver nas ruas e só. No entanto, ter emigrado me fez diferente e me deu mais maturidade, "não é fácil, mas agora, eu acho que consigo sobreviver sozinha".

\section{Ser jovem, mulher, negra e imigrante: realidade e representação}

Duas jovens mulheres negras e imigrantes em Portugal tentam, com muitos esforços, construírem a vida o melhor que possa, sem, no entanto, descuidarem-se dos seus semelhantes, outros imigrantes e suas famílias, conhecidos do bairro de invasão em que cresceram - a Quinta Grande. Significativo é o fato de ambas desenvolverem atividades de orientação, cooperação e outras entre jovens, crianças e famílias da ex-Quinta Grande e, agora, realojados, com apoio do ISU e, por extensão, muitas vezes, de orgãos públicos portugueses e da União Européia.

$\mathrm{O}$ que se percebe em seus trajetos é o vínculo com suas histórias pessoais e com a realidade portuguesa, porém, não se pode deixar de ver a influência nesses trajetos de aspectos próprios de uma cultura africana, em particular aquela que resulta das práticas e papéis femininos. Não por acaso, Vivi e Marizete trazem impressas em suas memórias e comportamentos, a realidade familiar, mesmo que marcada por conflitos e rupturas e, ainda, nomeadamente, a figura de outras mulheres, negras e africanas - a mãe, a avó, as tias e as primas. São elas ativadoras e suportes dos percursos até aqui cumpridos, bem como, permitem a ambas, aproximarem-se ou distanciarem-se dos projetos familiares em razão de tramas e itinerários próprios da mobilidade física e social no espaço - tanto na África, como em Portugal.

A mãe de Vivi, uma caixeira-viajante ${ }^{8}$ que transita, desde os anos de 1980, entre África, Brasil e Portugal, provavelmente por essa experiência, avalia e conclui pela necessidade de trazer sua filha para viver e estudar em Portugal, já que, por muito viajar não pode tê-la junto de si. Aciona então, a chamada família extensa, de modo a ter alguns membros da família em condições de receber sua filha em terras portuguesas. Assim, apesar dos desentendimentos com a mãe, será esta a decidir que venha para Portugal viver e morar com uma tia materna e, depois com uma tia-avó, isso depois de ter vivido, quando muito pequena, com a avó em São Tomé e com uma prima em Angola.

No caso de Marizete, também são mulheres a lhe determinarem o rumo de sua vida. A mãe, funcionária bem situada do Banco Nacional de Luanda tinha por origem uma família de posses em São Tomé, tal como se pode perceber na descrição das casas em que viveu nesse país e em Angola. Marizete ao falar de sua infância em São Tomé, relembra a casa enorme perto da praia, como também a vivenda do campo, no interior de uma vila, onde fez pré-primário e o avô era dono de uma grande empresa. Aos seis anos migra para a cidade a beira-mar, por decisão da avó materna que decide pela aposentadoria de seu avô e pelo seu ingresso na escola primária, "...uma escola de bom nome".

$\mathrm{Na}$ escola tem por professora uma prima de sua mãe, a quem a mãe dizia o que e como ensinar a filha e obrigá-la a estudar. Em Angola, Marizete passa a residir num condomínio e, segundo ela mesma, "em 
Luanda era muita gente...e a visão daquela menina que veio da roça, transformou-se completamente..." A mãe, no entanto, não gostou da transformação e a faz vir para Portugal, onde poderia estudar e ser alguém. Como diz Marizete:

...eu já estava me adaptando [em Luanda], mas tava abrindo os olhos demais. Tinha que ficar no controle [da mãe]. Porque ela queria uma filhinha assim...É claro que se tivesse ficado em Angola não teria toda a responsabilidade que tenho...nem teria a visão das coisas que eu tenho agora. Eu teria tudo à minha frente...eu poderia ter tudo o que queria, mas seria uma pessoa completamente diferente dos outros. O que eu quisesse, eu não saberia o preço daquilo...

Hoje, diz Marizete, a situação em Angola mudou e a mãe também sofreu revezes, de modo que não pode mais ajudá-la, como fez por um período de sua vida em Portugal e, ela agora, só tem a si mesma para contar. Isso quer dizer que migrar lhe ensinou muito, a começar pelo impacto que foi chegar a Quinta Grande, um bairro de lata, após ter vivido em casas grandes e confortáveis. Não por acaso, estranha tudo e diz jamais ter pensado em viver num bairro como aquele, tendo desejo de voltar, imediatamente para Luanda. No entanto, fica e é em Portugal que apreende e compreende a condição de ser imigrante, mulher e negra em terras estrangeiras. Também com Vivi, a história não é diferente.

Marizete fala muito de sua vida e trajetória, e o faz, buscando refletir seus próprios passos para aí ancorar sua visão de mundo, das coisas, do ser negra e de viver em Portugal. Muito reflexiva, demonstra ser uma negra que tenta e deseja adaptar-se aos padrões da sociedade portuguesa, ao mesmo tempo em que tenta aplicar um discurso de valorização de si mesma quando afirma que, se sofre algum tipo de discriminação, preconceito ou indelicadeza por ser negra, ignora e diz que a pessoa que assim age, necessita de tratamento. Como tal, é um doente.

Como mulher, demonstra ter consciência de que sua formação intelectual está mudando sua maneira de ser e de pensar, sobretudo, na relação homem/mulher. No entanto, encontra-se numa primeira relação afetiva mais duradoura e, tem por companheiro um homem africano e mulçumano. As posturas do companheiro são muito tradicionais e, para ele, a mulher deve servir ao homem e, isso ela já não aceita mais. No caso deles, ele ainda é um autêntico homem africano e, ela, não mais se vê como inteiramente africana, o que acarreta implicações para a vida afetiva e cotidiana. Marizete compreende que a orientação em termos da sexualidade para as portuguesas é diferente daquela que se espera de uma africana e que isso não está resolvido para ela mesma. Por essa razão, quando amigos portugueses fazem algumas provocações, ela ignora o assunto, no entanto, pelo lado das amizades africanas acontecem também, muitas cobranças. Como, portanto, ser africana e portuguesa a um só tempo? Apesar de não ter respostas, Marizete não vê perspectivas de voltar a ser uma mulher africana tradicional e tampouco pensa em voltar a viver na África.

Por sua vez, Vivi fala bastante do percurso de sua vida e de suas vivências, porém revela com maior clareza, os preconceitos que sofre por ser mulher, negra e imigrante. Diz ela,"eu sou uma pessoa que não dou margens às pessoas pizarem-me. Não dou! Quando me sinto pizada, espezinhada, eu faço logo confusão, eu falo!"

Com isso, Vivi aponta para as dificuldades de se viver em Portugal e, aponta para o fato da imigração ser o contexto que permite situar e compreender os problemas que o negro enfrenta no convívio com os portugueses, embora reconheça que também ocorre racismo entre negros.

Se eu entro em uma loja, eles [os portugueses] logo ficam pensando que vou roubar. Agora, imagina assim, se entrar quatro ou cinco negros, logo estão com o dedo por detrás do botão para carregar e avisar a polícia, porque eles [os portugueses] nunca pensam que nós vamos comprar, mas sim, roubar. Isso é racismo!

Mas o racismo está também presente na condição de ser mulher e de ser jovem. Para Vivi,

é muito difícil ser jovem e de origem africana em Portugal é...uma etapa muito dura porque somos mal encarados, porque somos explorados...Eu trabalhei, trabalhei e nunca tive desconto [previdência], nada disso! Trabalhava como escrava, mas eu na altura nem sequer pensava nisso, eu queria dinheiro e estava a precisar. É assim, com todos. Mas agora, ah! Quero todos os meus direitos, todos. Ah...ser jovem em Portugal...é muito complicado!

No entanto, diz Vivi,

ser jovem e mulher é...é melhor. Pronto! As mulheres têm mais facilidade de arranjar emprego. Porque tem a cozinha, tem a copa, não é?...Porque os rapazes é mais obra [construção civil] e eles não querem. Por isso é que muitas das vezes eles tornam-se vândalos, por causa disso. Não conseguem ter uma coisa daquilo que eles gostariam de exercer. Não conseguem. Muitas vezes, porque não têm estudo e, outras, tem estudo, mas é negro! Nós, mulheres, não. Nos metem logo na cozinha! Mesmo tendo estudo, vai lavar louça! 
Para Vivi, ser mulher e negra em Portugal é não poder ir muito longe e que, mesmo tendo estudo, dificilmente se é valorizada e cita como exemplo, o fato de que mulheres que são médicas na África migram e quando chegam a Portugal, vão para as limpezas (ser doméstica ou mulher a dias, como são chamadas as diaristas).

Por essa razão, Vivi, valoriza os estudos como forma, não só de melhorar as condições pessoais de vida, mas também para melhor se posicionar na sociedade de acolhimento, mas não tem muitas ilusões. Nesse sentido, entende que, apesar de melhor situada que muitos outros jovens do antigo bairro da Quinta Grande e, mesmo, no realojamento, ela não está deles distanciada. Sua formação não é ainda suficiente para poder impor-se socialmente. Afirma, assim, que em Portugal, com ou sem diploma todos os negros são discriminados e, que não é fácil ser jovem, mulher, negra e imigrante em Portugal.

Como mulher, entende que está envelhecendo rápido em razão de muito trabalhar e ganhar muito pouco. Diz que, "as pessoas que assistiram de perto a minha vida, olham para mim e dizem: 'Olha Vivi, tu tens essa idade, a idade que tu tens, o que tu sabes, nem parece ser a idade que tu tens, eu dava o triplo da tua idade'".

Envelhecer rápido, perder a juventude e não ter tempo para si, afeta também os projetos de constituir família, como bem demonstrou as falas de Marizete e, trás conseqüências quanto as possibilidades da vida afetiva. Vivi diz ter tido um namoro por cinco anos, com um rapaz branco e português, mas que foi obrigada a terminar a relação em razão dos conflitos de valores e de atitudes com relação à vida. Ele era viciado, "acabamos por causa dos vícios, a droga não sei o quê... acabei, pois aquilo não dava pra mim". Segundo Vivi, ela disse a ele, tudo que estava a lutar em sua vida, buscando melhorar e valorizar cada passo de sua trajetória e que não queria colocar em risco. Não foi, portanto, o problema da cor e da raça que os separou, mas, o projeto de vida que ela tinha para si mesma diante do que tem sido sua história. Agora, quatro anos depois, Vivi voltou a ter um namorado, um sãotomense como ela, porém mais velho e já com uma mentalidade totalmente diferente, "que vê as coisas de outro ponto de vista, faz-me perceber o que é e o que não é", é também trabalhador, um mecânico.

De sua parte, dá continuidade aos seus projetos, a trabalhar e ainda a dedicar-se aos meninos, crianças da Quinta Grande. Leva-os para a praia, a passear e tenta tirá-los "um bocado desse mundo que é pesado". Como diz: "É que não somos bem vistos". Como diz, tem muito orgulho de ser mulher e negra, mas viver em Portugal, já não é de muito orgulho. Orgulho seria poder estar na terra natal, mas, como diz, "tem que estar aqui [em Portugal] e ser explorada. Isso revolta ainda mais com minha terra que está a se passar o que se passa". Por essa razão, pensa que não é de tudo impossível voltar a viver em seu país - São Tomé -, "desde que, as coisas lá, melhorem, que está muito mal".

Vivi e Marizete, retratos vivos da contemporaneidade portuguesa, retratos que escondem por trás de seus sorrisos largos e olhares distantes, as dores da imigração, da condição de gênero e da raça. Porém, mais que tudo, os retratos dessas duas mulheres aqui traçados, fundamentalmente, pela energia que suas vidas revelam, dizem do que é ser jovem, mulher, negra e imigrante em Portugal, sem que, ambas, se coloquem numa condição de vítimas fadadas ao desfortunio e à falta da esperança.

Para encerrar esta breve apresentação e o grito de vida que essas histórias encerram, reproduzo abaixo o poema: Sou como uma estrela, de autoria de Marizete Francisco, de Junho de 1998.

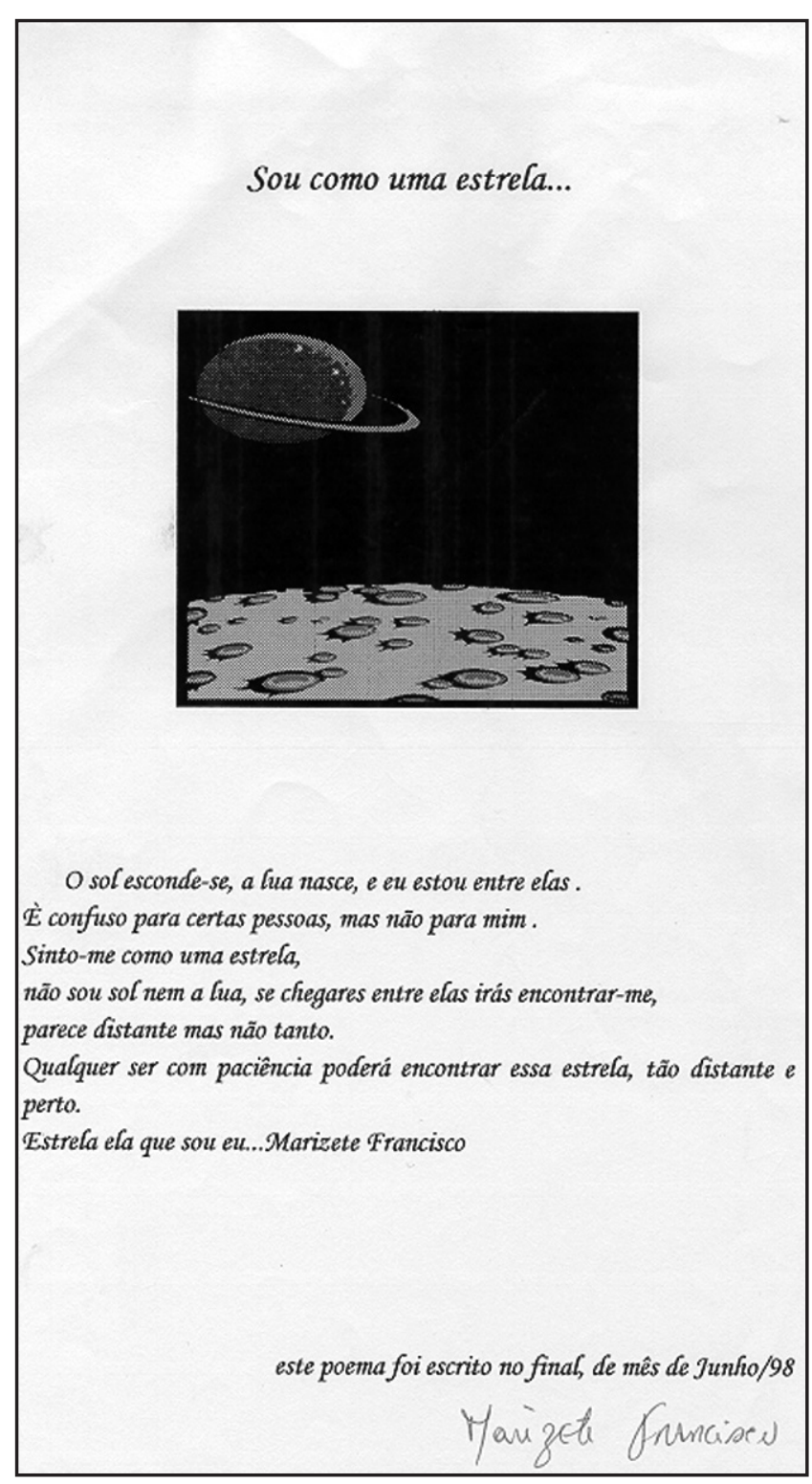




\title{
Referências
}

DUBET, François. Sociologia da experiência. Lisboa: Instituto Piaget, 1994.

GUSMÃO, Neusa Ma. Mendes de. Os Filhos da África em Portugal. Antropologia, Multiculturalidade e Educação. Belo Horizonte: Autêntica, 2005.

MARTINS, Humberto M. dos S. Ami Cunhá Cumpadri Pitécu: uma etnografia da linguagem e da cultura juvenil luso-africana em dois contextos suburbanos de Lisboa.
Lisboa, Dissertação (Mestrado)- Instituto de Ciências Sociais/Universidade de Lisboa, 1997.

MOORE, Henrietta L. Fantasias de poder e fantasias de identidade: gênero, raça e violência. Cadernos Pagu, v.14. Campinas: 2000, p. 15-44.

PAIS, José Machado. Culturas Juvenis. Lisboa: Imprensa Nacional, 1993.

\section{Young african women in Portugal: narratives and itineraries}

\begin{abstract}
This paper reports on the itineraries of two young African women, immigrants in Portugal, based on their own narratives. In the story of their lives, other stories emerge to reveal what it means to be young, female, black and immigrant in the present European context. Their narratives are interlaced by childhood memories in Africa or even in Portugal and also refer to their youth lived in the African district Aldeia d'África, in Portuguese land. Thus, Portugal and Africa weave together the threads of their everyday lives, allowing through different evidences the understanding of these biographies, memory and culture, as they are presented in each one's personal experience. An experience that reveals the story of many other African women in Portugal.
\end{abstract}

Key-words: Africa, immigrant, narrative, culture, itinerary.

Data de recebimento do artigo: 15 de fevereiro de 2008

Data de aprovação do artigo: 22 de abril de 2008 